Hydrol. Earth Syst. Sci. Discuss.,

https://doi.org/10.5194/hess-2020-283-RC1, 2020

(c) Author(s) 2020. This work is distributed under

the Creative Commons Attribution 4.0 License.

\title{
Hydrology and

\section{Interactive comment on "Reservoir evaporation in a Mediterranean climate: Comparing direct methods in Alqueva Reservoir, Portugal' by Carlos Miranda Rodrigues et al.}

\section{Femke Jansen (Referee)}

femke.jansen@wur.nl

Received and published: 13 August 2020

The comment was uploaded in the form of a supplement:

https://hess.copernicus.org/preprints/hess-2020-283/hess-2020-283-RC1-

supplement.pdf

Interactive comment on Hydrol. Earth Syst. Sci. Discuss., https://doi.org/10.5194/hess-2020-

Printer-friendly version 283, 2020. 